\title{
In vivo distribution of human milk leucocytes after ingestion by newborn baboons
}

\author{
L JAIN, * D VIDYASAGAR, ${ }^{*}$ M XANTHOU, $\ddagger$ V GHAI, * S SHIMADA, AND \\ M BLEND† \\ Departments of *Pediatrics and $†$ Nuclear Medicine, University of Illinois at Chicago, USA and $\ddagger$ Department \\ of Paediatrics, Agha Sophia Hospital, Athens, Greece
}

SUMMARY The in vivo distribution of enterally administered human milk leucocytes labelled with indium hydroxyquinoline $\left({ }^{111} \mathrm{In}\right)$ was studied in premature baboons. The animals were killed at 72 hours of age and tissue samples examined for radioactivity. Maximum activity was found in the luminal contents, and activity in the liver and spleen was higher than in bone marrow, the site where free isotope is normally deposited. These findings suggest that some intact milk leucocytes may cross from the gastrointestinal tract into the neonatal circulation. Also the high activity in gastrointestinal tissue that had been washed several times indicates that leucocytes adhere to mucosa or lie intramurally. We speculate that the presence of leucocytes in the gastrointestinal tract 60 hours after a single breast feed can provide an important defence mechanism against infection.

Research continues to show the scientific benefits of breast feeding. ${ }^{1}$ These benefits are not limited to nutritional elements alone, as breast milk contains many active immunological components including immunoglobulins and numerous cells. ${ }^{2}$ By transfer of these factors, breast feeding has been implicated in maintaining immunological homoeostasis in the neonatal intestine during the period of immaturity of the immune system. . $^{3-6}$

Although the presence of functioning leucocytes in milk has been shown in vitro by various investigators, ${ }^{7-9}$ their in vivo function after ingestion by the newborn has not been widely studied. There is also a lack of information about their migration pattern. The present investigation was designed to study the distribution and migration pattern of human milk leucocytes in the gastrointestinal tract of premature newborn baboons.

\section{Material and methods}

The study was approved by the Institutional Review Board and Animal Care Committee. In our laboratory a baboon fetus delivered at a mean gestational age of 140 days (normal gestation period 184 days) has been used to study hyaline membrane disease; details of the preparation of the animals have been previously described. ${ }^{10}$ We therefore used the existing animal model to study the kinetics of human milk leucocytes.
Animals were delivered by caesarean section at a mean (SD) gestational age of 140 (2) days and were anaesthetised with ketamine. A tracheostomy was carried out for control of the airway and management of secretions. The external jugular vein was cannulated for infusion of fluids. Studies of human milk leucocytes were started when the animals were stable. Labelled cells suspended in phosphate buffered saline were given through a nasogastric tube at less than 12 hours of age. Animals received no other feeds before or after the cells were given (table 1).

\section{ISOLATION OF MILK LEUCOCYTES}

Samples of human milk were collected by manual expression from healthy mothers between two and 10 days after delivery and immediately processed using modification of the technique of Ogra and Ogra. ${ }^{11}$ The method for the separation of the leucocytes is shown in table 2.

LABELLING OF LEUCOCYTES

The method for the labelling of the leucocytes is shown in table 3 .

Blood samples were obtained through an indwelling central venous catheter at 0 and 72 hours. Animals were killed at 72 hours and tissue samples obtained from various organs. The degree of leucocyte sequestration was determined by counting the radioactivity/g of tissue and was expressed as multiples of the activity in the blood. 
Table 1 Details of study in primate model

1 Six premature baboons, delivered at 140 days' gestation, were stabilised and maintained alive for 72 hours

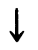

2 A suspension of labelled cells was fed through a nasogastric tube at $<12$ hours of age

\section{$\downarrow$}

3 Serial samples of blood, urine, and meconium were collected at 12 hour intervals

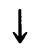

4 Animals were killed at 72 hours of age and radioactive counts performed on tissue samples obtained from liver, spleen, bone marrow, and various parts of the gastrointestinal tract

Table 2 Isolation of milk leucocytes

1 Human breast milk was obtained from lactating mothers $<10$ days' postpartum; $30 \mathrm{ml}$ fresh sample was used for each experiment

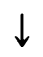

2 Milk was defatted by cold centrifugation at $400 \mathrm{~g}$ for 30 minutes

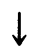

3 Supernatant with fat layer was aspirated and fat globules removed

4 Cell buttons were agitated and washed three times in phosphate buffered saline then resuspended in phosphate buffered saline

\section{$\downarrow$}

5 Total and differential counts were performed and cells tested for viability with trypan blue staining

\section{Results}

Seven animals were studied; one died on the second day of the experiment and was excluded from analysis. The four male and two female animals had a mean (SD) birth weight of 550 (110) $\mathrm{g}$ and gestational age 140 (2) days.

The yield of milk cells varied widely with a mean of $5 \times 10^{6}\left(2 \times 10^{5}\right)$ cells $/ \mathrm{ml}$. The predominant cells were macrophages and polymorphonuclear leucocytes, with a small proportion of lymphocytes. As
Table 3 Labelling of leucocytes

1 A known amount of indium hydroxyquinoline ( ${ }^{111}$ In) was added to the suspension of washed human milk leucocytes

2 The suspension was incubated at room temperature for $\mathbf{3 0}$ minutes

3 (a) Incubated cells were centrifuged at $400 \mathrm{~g}$ for 6 minutes

(b) Supernatant was removed and labelled 'wash'

(c) Cells were resuspended in $2 \mathrm{ml}$ phosphate buffered saline

4 Indium hydroxyquinoline ( ${ }^{111}$ In) activity was determined in cells and wash, and labelling efficiency calculated as follows:

$$
\%=\frac{\mathrm{Bq} \text { in labelled cells }}{(\mathrm{Bq} \text { in cells and wash) }} \times 100
$$

${ }^{111}$ In binds avidly with all blood cells, the following data reflect activity of a mixed population of macrophages and polymorphs. Mean (SD) labelling efficiency with ${ }^{11}$ In was $46.8(7) \%$. With this technique, the dose of indium given to the animals in labelled cells was in the range of $1.85 \times 10^{6}$ to 3.7 $\times 10^{6} \mathrm{~Bq}$.

The distribution of radioactivity in tissue samples collected at necropsy is shown in table 4. Activity/g tissue was expressed as multiples of activity in blood. Maximum activity was found in gastric fluid and meconium. Washed small intestine had the highest radioactivity among tissue samples, followed by the stomach and the large intestine. Bone marrow had counts comparable with those in blood. Liver and spleen, however, had counts significantly higher than those in blood and bone marrow $(\mathrm{p}<0 \cdot 05)$.

\section{Discussion}

The white cells of human colostrum were first observed in 1839 by the biologist and photographer Alexander Donne, and rediscovered in 1966 by Smith and Goldman. ${ }^{12}$ Early colostrum contains the highest concentration of cells ranging from 1-3 $\times$ $10^{6-8}$ cells $/ \mathrm{ml}$. Toward the end of the first five weeks of lactation the cell concentration drops to about $10^{5}$ cells $/ \mathrm{ml}^{13}$ Cell counts obtained in our study were within this range. 
Table 4 Radioactivity in specimens obtained from the gastrointestinal tract and systemic tissues. The radioactivity was measured as counts/minute/g sample and expressed as multiples of activity in blood

\begin{tabular}{lc}
\hline Mean (SEM) activity in counts/minute/g sample \\
\hline Gastrointestinal lumenal contents: & $202 \cdot 0(64 \cdot 0)$ \\
Gastric contents & $144 \cdot 0(37 \cdot 0)$ \\
Meconium & \\
Washed gastrointestinal tissue: & $22 \cdot 4(6 \cdot 0)$ \\
Gastric tissue & $142 \cdot 0(42 \cdot 0)$ \\
Small intestine & $12 \cdot 4(5 \cdot 1)$ \\
Large intestine & \\
Systemic tissues: & $9 \cdot 5(4 \cdot 0)$ \\
Liver & $9 \cdot 1(2 \cdot 8)$ \\
Spleen & $1 \cdot 4(0 \cdot 23)$ \\
Bone marrow & $1 \cdot 0$ \\
Blood (reference) & \\
\hline
\end{tabular}

Numerous observations have been made about the functional value of human milk leucocytes, most of which have been based on in vitro studies. Milk cells are actively phagocytic and microbicidal. ${ }^{89}$ Milk phagocytes adhere to and spread on glass. ${ }^{8}{ }^{9}$ In a recent study human milk macrophages were shown to be motile in collagen gels. ${ }^{14}$ Human milk phagocytes elicit antibody dependent cytotoxicity, ${ }^{15}$ and give a good metabolic response as measured by chemiluminesence. ${ }^{16}$ Whether these in vitro observations hold true in vivo conditions is not known. Our study was designed to investigate the in vivo distribution of milk leucocytes after ingestion by newborn baboons, and three important findings emerged; first, it is possible to use ${ }^{111}$ In as a marker for human milk leucocytes; secondly, it is likely that some milk leucocytes enter the systemic circulation; and thirdly human milk leucocytes seem to persist in the intestine for a long period after a single feed.

The radioactive tracer ${ }^{111}$ In labelled to a mixed population of white blood cells has been used in adults for the diagnosis of occult infections. ${ }^{17-19}$ The technique of labelling neutrophils with a gamma emitting radionuclide was first evaluated in 1976 by Thakur et $^{a l^{17}}{ }^{18}$ and has been used in patients since then. The technique is based on the passive diffusion of ${ }^{111}$ In chelated with 8-hydroxyquinoline. In previous studies investigators have used different markers to study milk leucocytes,${ }^{20}$ but ${ }^{111}$ In has not been previously reported. In the present study, using relatively small amounts we achieved about $50 \%$ labelling efficiency. The technique is comparatively simple and takes less than an hour. The presence of transferrin and fat have been shown to interfere with labelling ${ }^{17}$; this effect can be minimised by thorough washing of the cells.
Awareness that viable leucocytes are present in colostrum and milk has stimulated interest in the importance of these cells. ${ }^{21}$ Tests of skin grafting on foster nursed rats and mice have provided circumstantial evidence that, in these species, leucocytes may be transmitted naturally from the mother's blood stream to the suckling's blood stream through the milk. ${ }^{22}$ In the present study we have shown that it is possible that some of the milk leucocytes crossed the intestinal barrier of the premature animal and entered its circulation. This speculation stems from analysis of the systemic distribution of ${ }^{111}$ In at necropsy. One might assume that the high ${ }^{111}$ In activity found in liver and spleen could represent free isotype. Although we did not have a group of control animals that were given free indium, our interpretation of the distribution data is based on previous studies. ${ }^{17} 192324{ }^{111}$ In does not eluate from the living cells: after death of the cells and release of the ${ }^{11}$ In it is bound to proteins such as transferrin and is eventually deposited in the bone marrow. ${ }^{23}$ Also, because plasma ${ }^{111}$ In activity tends to remain constant and persists after all labelled granulocytes have disappeared from the blood, it seems that organ activity reflects uptake of cell bound ${ }^{111}$ In and not plasma ${ }^{111}$ In. ${ }^{24}$ The higher activity in the liver and spleen than in the bone marrow that we found is consistent with the distribution of the radioisotope when labelled leucocytes are injected intravenously. ${ }^{25}$

Such a transfer of milk leucocytes into the systemic circulation after breast feeding in newborn primates has not been reported before, although Beer and Billingham produced strong evidence that it occurred in certain species of rats and mice. ${ }^{21}$

Neither the $\mathrm{pH}$ nor the enzyme content of the infants' stomachs are likely to be harmful to the ingested cells ${ }^{24} 26$; in our study the $\mathrm{pH}$ of stomach contents was about 7.0. Also the high buffering capacity of milk may be important in protecting its cellular elements.

It has been suggested that breast milk has a protective effect in necrotising enterocolitis and other infectious diseases, ${ }^{27}$ but the mechanism of protection is not clear. Kmetz et al have shown that when newborn rabbits were fed labelled, viable bovine leucocytes, the cells were found beneath the epithelium of the mucous membranes of the oesophagus and stomach ${ }^{28}$ This apparent ability of mothers to 'transplant' leucocytes naturally to their young through the milk may play an important part in preventing necrotising enterocolitis. In this study we have shown that human milk leucocytes adhere to mucosa or lie intramurally 60 hours after ingestion of a single feed. A recent investigation in which the authors proposed that macrophages may pene- 
trate into mucosal sites for host defense supports this view. ${ }^{14}$ If this is true it would make a strong case for the prophylactic administration of human milk leucocytes separàted from the breast milk of lactating mothers to premature infants who otherwise cannot tolerate enteral feeds. There is, however, a risk if the donor is not the infant's biological mother.

A few questions still remain to be answered. We used heterologous milk leucocytes; thus there is difficulty in the interpretation of data on kinetics. The difficulties encountered in conducting such studies in human subjects are well understood, and therefore a non-human primate was used. The second question is whether the radioactivity measured in the gastrointestinal tract and other tissues truly reflects the presence of intact human milk leucocytes or leached ${ }^{111}$ In. Studies by Thakur et al have shown that ${ }^{111}$ In binds firmly at intracytoplasmic sites, and is usually released only if the cell dies. ${ }^{17}$ The released isotope would then be deposited freely in tissues, especially the bone marrow. The fact that a higher amount of radioactivity was found in the liver and spleen and only a minimal amount in bone marrow supports our hypothesis that human milk leucocytes were intact. The mechanism by which human milk leucocytes cross from the gastrointestinal tract into the systemic circulation has yet to be elucidated.

Based on these observations we speculate that human milk leucocytes, once ingested, may remain in the intestine for as long as $\mathbf{6 0}$ hours. Those cells that cross the intestine reach sites of the reticuloendothelial system, namely the liver and spleen. The persistence of these cells in the intestinal tract for long periods after a feed suggests the important protective role of milk leucocytes.

\section{References}

1 Goldman AS, Garza C. Future research in human milk. Pediatr Res 1987;22:493-6.

2 Ogra SS, Ogra PL. Components of immunologic reactivity in human colostrum and milk. In: Ogra PL, Dayton DH, eds. Immunology of breast milk. New York: Raven Press, 1979:18595.

3 Rogers HJ, Synge C. Bacteriostatic effect of human milk on Escherichia coli: the role of IgA. Immunology 1979;34:19-28.

4 Winberg J, Wessner G. Does breast milk protect against septicaemia in newborn? Lancet 1971;i:1091-4.

5 Chandra RK. Prospective studies of the effect of breast feeding on incidence of infection and allergy. Acta Paediatr Scand 1979;19:694.

${ }^{6}$ Head JR, Beer AE. In vivo and in vitro assessment of the immunologic role of leukocyte cells in milk. In Ogra PL, Dayton DH. eds. Immunology of breast milk. New York: Raven Press, 1979:207-25.

7 Lascelles AK, Gurner BW, Coombs RR. Some properties of human colostral cells. Aust J Exp Biol Med Sci 1969:47:349-60.

8 Mohr JA, Leu R, Mabry W. Colostral leukocytes. J Surg Oncol 1970;2:163-7.
9 Pitt J. The milk mononuclear phagocyte. Pediatrics 1979;64 (suppl):745-9.

10 Vidyasagar D, Maeta H, Raju TNK, et al. Bovine surfactant (surfactant TA) therapy in immature baboons with hyaline membrane disease. Pediatrics 1985;75:1132-42.

11 Ogra SS, Ogra PL. Immunologic aspects of human colostrum and milk II. Characteristics of lymphocyte reactivity and distribution of E-rosette forming cells at different times after the onset of lactation. $J$ Pediatr 1978;92:550-5.

12 Smith CW, Goldman AS. The cells of human colostrum I. In vitro studies of morphology and function. Pediatr Res 1968;2: 103-9.

13 Xanthou M, Mandyla-Sfagou H, Maravelias C, Baum JD, Matsaniotis N. Phagocytes of human colostrum and their function. In: Stern L, Salle B, Friis-Hansen B, eds. Intensive care in the newborn III. New York: Masson, 1981:201-11.

14 Ozkaragoz H, Rudloff HB, Rajaraman S, Mushtaha AA, Schmalstieg FC, Goldman AS. The motility of human milk macrophages in collagen gels. Pediatr Res 1988;23:449-52.

15 Mandyla H, Xanthou M, Maravelias C, Baum D, Matsanistis N. Antibody dependent cytotoxicity of human colostrum phagocytes. Pediatr Res 1982;16:995-9.

${ }^{16}$ Mandyla H, Xanthou M. Function of leukocytes in human milk. In: Hamosh M, Goldman AS, eds. Human lactation 2-maternal and environmental factors. New York: Plenum Press, 1986: 533-40.

17 Thakur ML, Lavender JP, Arnot RN, et al. "'Indium labelled autologous leukocytes in man. J Nucl Med 1977;18:1014.

18 Segal AW, Thakur ML, Arnot RN, et al. "11' Indium labelled leucocytes for localisation of abscesses. Lancet 1976;ii:1056-8.

19 Goodwin DA, Doherty PW, McDougall IR. Clinical use of indium "I' labelled white cells; an analysis of 312 cases. In: Thakur ML, Goltschalk A, eds. "'Indium labeled neutrophils, platelets and lymphocytes. New York: Trivirum, 1981:131-45.

20 Parmerly MJ, Beer AE, Billingham $R$. In vitro studies on the $T$ lymphocyte population of human milk. J Exp Med 1976;144: 358-70.

21 Beer AE, Billingham RE. Immunologic benefits and hazards of milk in maternal-perinatal relationship. Ann Intern Med 1975; 83:865-71.

22 Goodwin DA, Meares CF. Indium "II labelled cells. New approaches and radiation dosimetry. In: Thakur ML, ed. Radiolabelled cellular blood elements. New York: Plenum Press, 1985:356.

23 Peters AM, Saverymuttu SH, Lavender JP. Granulocyte kinetics. In: Thakur ML, Radiolabelled cellular blood elements. New York: Plenum Press, 1985:356.

24 Beer AE, Billingham AE, Head J. The immunologic significance of mammary gland. J Invest Dermatol 1974;63:65-74.

25 Product information on indium hydroxyquinoline. Amersham: Amersham International, 1986.

${ }^{26}$ Manville IA, Lloyd RW. The hydrogen ion concentration of the gastric juice of fetal and newborn rats. Am J Physiol 1932;100: 394-401.

27 Boass A, Wilson JH. Development of mechanisms for intestinal absorption of infamin $\mathrm{B}^{12}$ in growing rats. Am J Physiol 1963;204:101-4.

${ }^{28} \mathrm{Kmetz}$ M, Dunne HW, Schultz RD. Leukocytes as carriers in the transmission of bovine leukaemia: invasion of the digestive tract of the newborn by ingested cultured leukocytes. Am J Vet Res 1970;31:637-41.

29 Barlon B, Santilli TV, Haird WC, Pitt J, Blanc WA, Schullinger JN. An experimental study of acute neonatal enterocolitis. The importance of breast milk. J Pediatr Surg 1974;5:587-95.

Correspondence and requests for reprints to Dr D Vidyasagar, Department of Pediatrics, University of Illinois at Chicago, 840 South Wood Street, Chicago, Illinois 60612, USA.

Accepted 17 November 1988 